\title{
PEMBINAAN KERAPIHAN ADMINISTRASI MENGGUNAKAN MICROSOFT OFFICE PADA IBU PKK KAVLING KAMBOJA SAGULUNG
}

\author{
Nia Ekawati \\ Politeknik TEDC, Bandung, Indonesia \\ e-mail: niaekawati1@gmail.com \\ Rico Adrial \\ Universitas Andalas, Padang, Indonesia \\ e-mail: ricoadrial@yahoo.com
}

\begin{abstract}
Information technology is currently well known by many people, such as children, teenagers, adults, and even parents nowadays, they must follow the latest technology, one of which is Microsoft office technology. Everyone knows this in schools, offices, and institutions. One of them is the women of Family Welfare Development (PKK) in the Kavling Kamboja RT 02 RW 03, Sei Pelungut Village, Sagulung District. PKK women in this area are quite active in various ways, of course, in the administrative process implemented at the Microsoft office, these PKK women must be orderly such as the correspondence process, making activity announcements, and managing household budgets in the PKK environment. Currently Microsoft office always makes new breakthroughs by updating its application to Microsoft office 2013. However, PKK women in the Kavling Kamboja want to learn administration in a simple way, so I try to use Microsoft office 2013. I use the application, because currently the process is correspondence is still asking for typing services, many PKK women still don't understand how to use Microsoft office. So the servants tried from the simple ones first, and the continuity of this activity could be understood by the PKK women.
\end{abstract}

Keywords-Microsoft Office, PKK, Correspondence, Typing, Services

\section{PENDAHULUAN}

Teknologi Informasi saat ini cukup diketahui oleh banyak kalangan, seperti anak-anak, remaja, orang dewasa dan bahkan orang tua di jaman sekarang ini harus mengikuti teknologi terbaru, salah satunya adalah teknologi Microsoft office. Semua kalangan mengenal ini di lingkungan sekolah, perkantoran dan kelembagaan. Salah satunya adalah Ibu-ibu Pembinaan Kesejahteraan Keluarga (PKK) daerah Kavling Kamboja RT 02 RW 03 Kelurahan Sei Pelungut Kecamatan Sagulung. Ibu-ibu PKK di daerah ini cukup aktif dalam berbagai hal, tentunya dalam proses administrasi yang diimplementasikan pada Microsoft office, ibu-ibu PKK ini harus tertib seperti proses surat menyurat, membuat pengumuman kegiatan, dan mengatur anggaran rumah tangga di lingkungan PKK.

Pengabdian yang dilakukan oleh (Rustandi, Andi; Febriani, R. Bunga; Sugiarto, 2019) berupa training English for Business dan English for Tourism yang diadakan pada ibu-ibu PKK Desa Sukaresik, pelatihan ini diharapkan dapat menumbukan penjualan produk kerajinan yang berguna untuk memajukan 
kesejahteraan keluarga miskin daerah kabupaten Ciamis. Bidikan dari training ini yaitu ibu-ibu PKK Desa Sukaresik, Kecamatan Sindangaasih, Kabupaten Ciamis. Cita-cita yang ingin dicapai, ibu-ibu PKK memiliki kapabilitas dasar dalam berkomunikasi bahasa inggris yang benar dan baik pada proses menjual kerajinannya. Teknik yang dipakai oleh kelompok pengabdian yaitu mengalihkan komunikasi English for Business dan English for Tourism ibu-ibu PKK dengan cara training. Training ini meliputi 1) menyampaikan materi dasar, dan 2) melaksanakan praktek komunikasi. Saat ini Microsoft office 2013 selalu melakukan terobosan baru dengan mengupdate aplikasinya ke Microsoft office 2013. Namun ibu-ibu PKK yang ada di daerah kavling kamboja menginginkan belajar administrasi secara sederhana, maka pengabdi mencoba menggunakan Microsoft office. Pengabdi menggunakan aplikasi tersebut, karena saat ini proses surat menyurat masih meminta pada jasa pengetikan, ibu-ibu PKK masih banyak yang belum memahami bagaimana cara menggunakan Microsoft office. Maka pengabdi mencoba dari yang sederhana terlebih dahulu, dan keberlanjutan kegiatan ini dapat dipahami oleh ibu-ibu PKK tersebut (LPPM, 2016). Berdasarkan uraian diatas, permasalahan yang muncul adalah sebagai berikut: 1). Administrasi pada kegiatan PKK di kavling kamboja masih menggunakan jasa pengetikan, dan 2) Ibu-ibu PKK masih banyak yang belum mengetahui penggunaan Microsoft office.

\section{METODE}

Pengabdian yang dilakukan oleh (Alifiana, 2018) Pengabdian yang dilakukan pada Desa Mlati Norowoti RT 01 RW 07, Kabupaten Kudus dikhususkan untuk Ibu PKK yang bertujuan untuk mentraining anggota PKK supaya ahli membuat kerajinan aksesoris hijab serta memajukan penghasilan keluarga. Teknik yang dipakai dalam kegiatan ini yaitu penyuluhan dan training wirausaha membuat kerajinan aksesoris hijab handmade. Tim ibu PKK sangat gembira dengan kegiatan ini. Ibu PKK dapat membiasakan membuat aksesoris menggunakan bahan akrilik sebagai dasarnya. Berdasarkan kegiatan pengabdian pada tim PKK RT 01 RW 07, Desa Mlati Norowito hasil yang diperoleh adalah berupaya membuat kerajinan aksesoris hijab handmade sehingga dapat mencapai ke tahap penjualan. Sebagai penghasilan tambahan keluarga warga RT 01 RW 07, aksesoris ini telah dijual diantara anggota dan warga setempat.

Berdasarkan uraian diatas, permasalahan yang muncul adalah sebagai berikut: 1). Administrasi pada kegiatan PKK di kavling kamboja masih menggunakan jasa pengetikan, dan 2) Ibu-ibu PKK masih banyak yang belum mengetahui penggunaan Microsoft office. Solusi dari permasalahan tersebut adalah sebagai berikut: 1). Mengajarkan ibu-ibu PKK untuk menggunakan Microsoft office, dan 2) Mengajarkan bagaimana cara membuat administrasi di PKK menjadi lebih baik tanpa bantuan jasa pengetikan.

Metode yang digunakan dalam pelaksanaan pengabdian kepada masyarakat di Kavling Kamboja RT 02 RW 03 Kelurahan Sei Pelungut Kecamatan Sagulung secara rinci untuk memecahkan permasalahan mengenai belum adanya administrasi yang baik pada lbu-ibu PKK di Kavling Kamboja RT 02 RW 03 Kelurahan Sei Pelungut Kecamatan Sagulung. Metode pelaksanaan dan implementasi dilakukan dengan proses pembinaan yang dilaksanakan oleh 2 (dua) orang diantaranya adalah sebagai berikut: 
Tabel 1. Metode Pelaksanaan dan implementasi

\begin{tabular}{|c|l|l|}
\hline Pertemuan & \multicolumn{1}{|c|}{ Pemateri } & \multicolumn{1}{c|}{ Materi yang disampaikan } \\
\hline 1 & $\begin{array}{l}\text { Nia Ekawati, S. Kom., } \\
\text { M.SI }\end{array}$ & $\begin{array}{l}\text { Mengenalkan Microsoft office secara } \\
\text { umum mengenai ikon-ikon pada } \\
\text { bagian ribbon }\end{array}$ \\
\cline { 2 - 4 } & Rico Adrial, M. Si & $\begin{array}{l}\text { Menyampaikan materi mengenai } \\
\text { kegunaan istilah pada Microsoft office }\end{array}$ \\
\hline 2 & $\begin{array}{l}\text { Nia Ekawati, S. Kom., } \\
\text { M.SI }\end{array}$ & $\begin{array}{l}\text { Praktek Microsoft office (pembuatan } \\
\text { nomor otomatis, pembuatan grafik) } \\
\text { dan praktek pembuatan e-mail }\end{array}$ \\
\cline { 2 - 4 } & Rico Adrial, M. Si & $\begin{array}{l}\text { Praktek Microsoft office (pembuatan } \\
\text { nama kolom dan kerapihan) }\end{array}$ \\
\hline 3 & Nia Ekawati, S. Kom., & $\begin{array}{l}\text { Praktek Microsoft office (pembuatan } \\
\text { surat, perhitungan penjumlahan dan } \\
\text { rata-rata nilai) }\end{array}$ \\
\cline { 2 - 3 } & Rico Adrial, M. Si & $\begin{array}{l}\text { Praktek Microsoft office (pembuatan } \\
\text { presentasi kegiatan, perhitungan } \\
\text { pengurangan dan logika pengandaian } \\
\text { IF then) }\end{array}$ \\
\hline
\end{tabular}

Proses dari pelaksanaan kegiatan pengabdian kepada masyarakat tentunya memerlukan evaluasi dari pelaksanaan kegiatan tersebut, diantaranya: 1) Ibu PKK Kavling Kamboja RT 02 RW 03 Kelurahan Sei Pelungut Kecamatan Sagulung dapat mengimplementasikan pembinaan yang telah dilaksanakan dikemudian hari, dan 2) Ibu PKK Kavling Kamboja RT 02 RW 03 Kelurahan Sei Pelungut Kecamatan Sagulung memiliki administrasi dengan baik dan tidak tergantung pada jasa pengetikan. Berikut foto-foto kegiatan Bersama Ibu PKK Kavling Kamboja RT 02 RW 03 Kelurahan Sei Pelungut Kecamatan Sagulung.

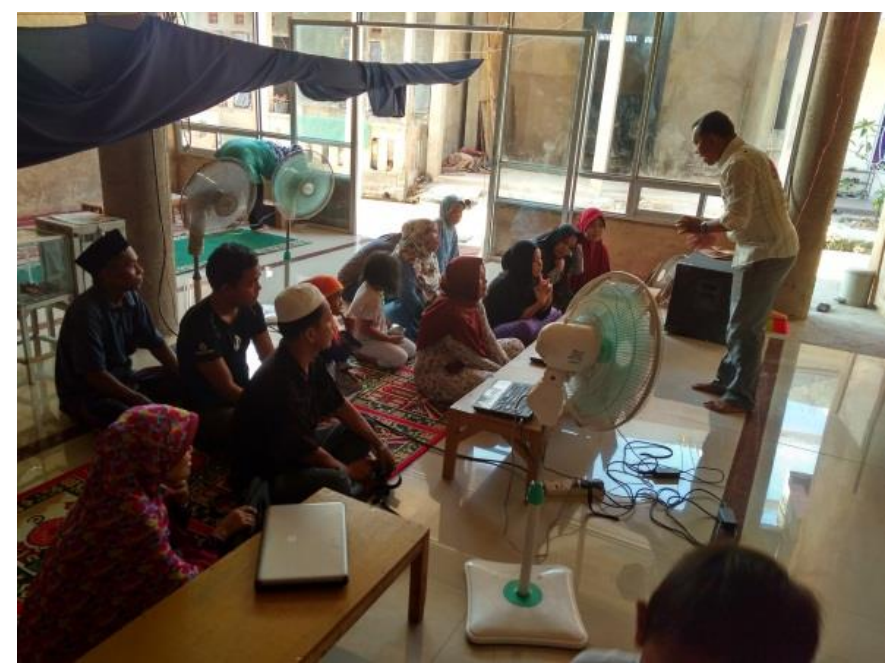

Gambar 1. Pembukaan materi pertemuan ke 1 


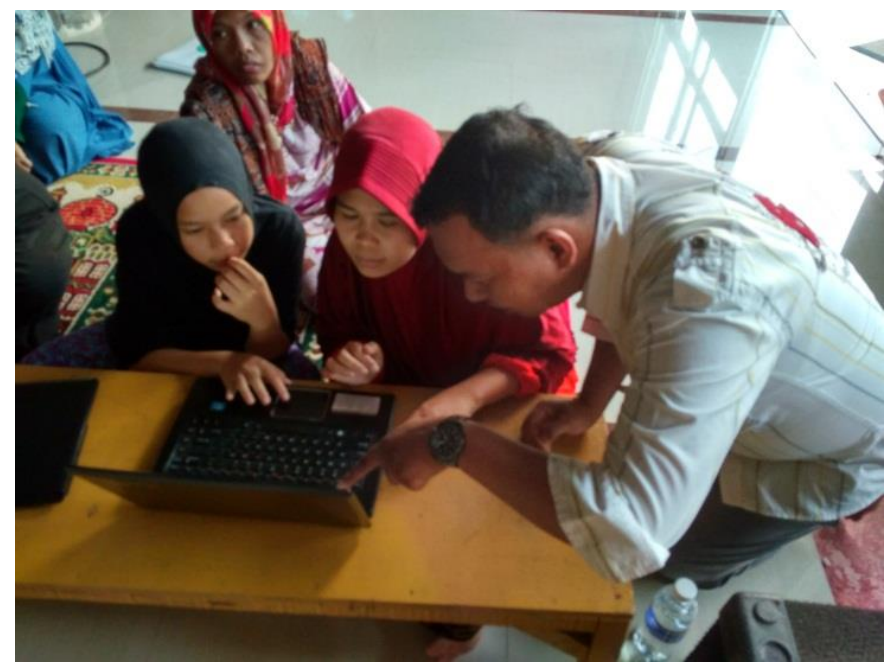

Gambar 2. Penyampaian materi pertemuan ke 1

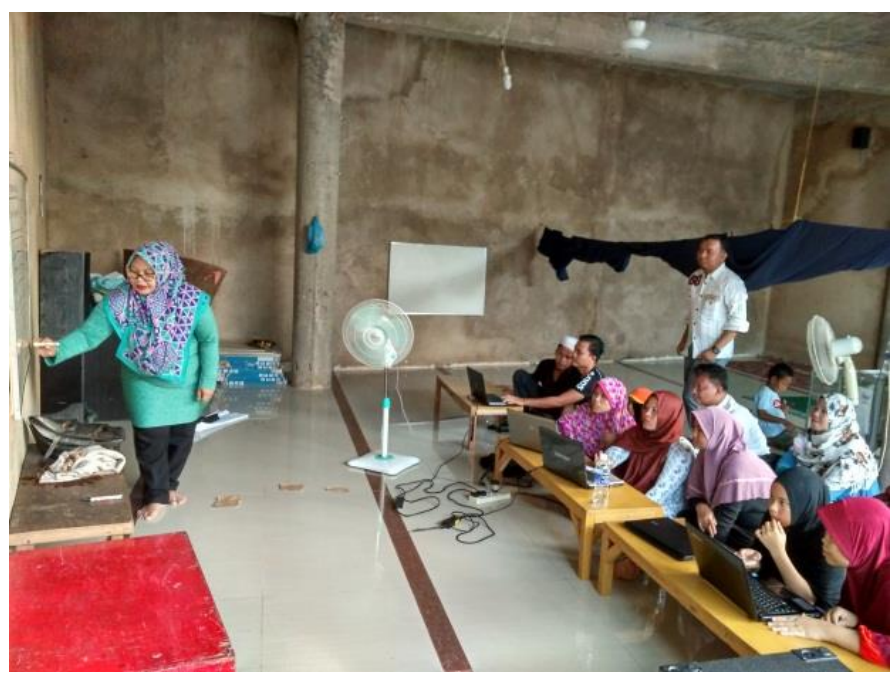

Gambar 3. Penyampaian materi pertemuan ke 2

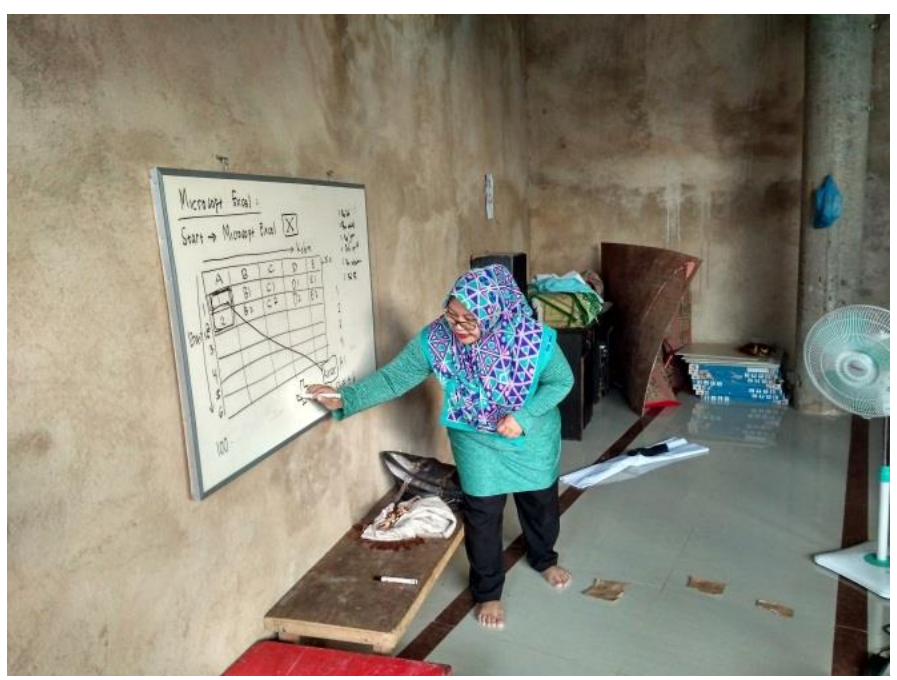

Gambar 4. Penyampaian materi pertemuan ke 2 


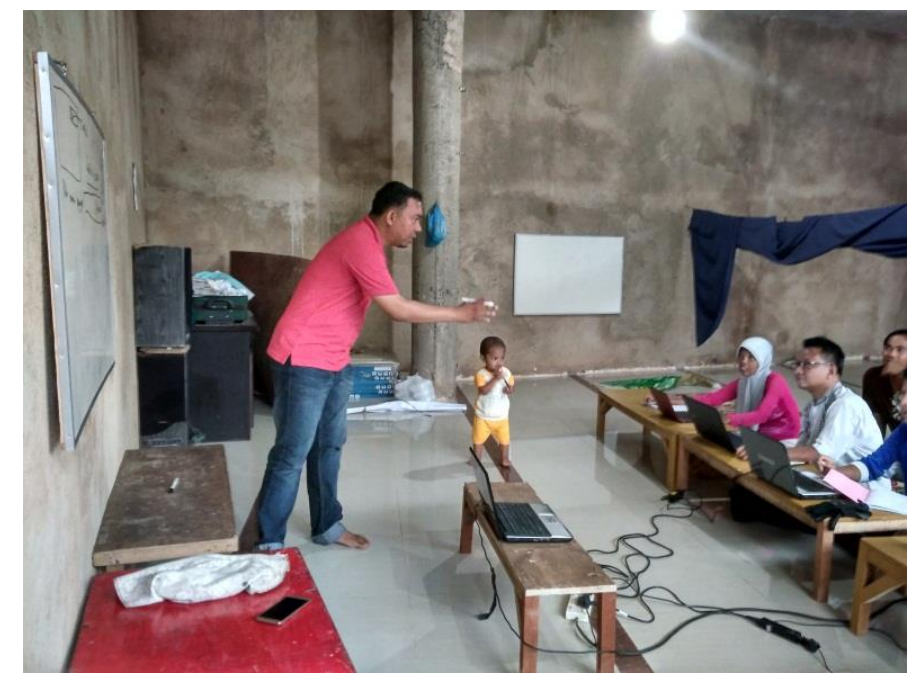

Gambar 5. Penyampaian materi pertemuan ke 3

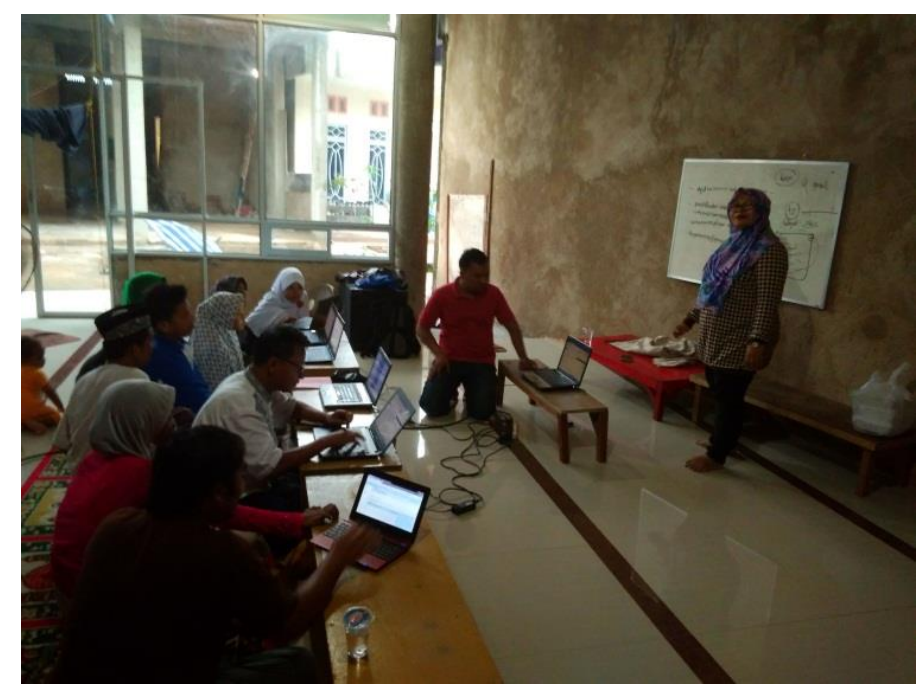

Gambar 6. Penyampaian materi pertemuan ke 3

\subsection{Hasil}

\section{HASIL DAN PEMBAHASAN}

Pelaksanaan dilakukan secara spontan dalam artian langsung praktek mengenai Microsoft office 2013,. Disela-sela pemberian materi di hari ke-2 (pertemuan ke-2) pengabdi memberikan bonus ajaran mengenai pembuatan $e-$ mail, materi ini tidak ada dalam judul pengabdian kepada masyarakat, karena hal tersebut merupakan permintaan dari peserta pengabdian. Saat pemberian materi peserta memang sudah memiliki e-mail, namun rata-rata dibuatkan oleh teman atau kerabatnya, jadi para peserta pengabdian meminta kepada pengabdi untuk mengajarkan cara pembuatan e-mail. Pengabdi mengajarkan beberapa materi yaitu Microsoft office 2013 yang selanjutnya memberikan tugas pada perseta pengabdian diakhir pertemuan pengabdian kepada masyarakat dikirim melalui $e$ mail yang telah dibuat oleh masing-masing peserta pengabdian. 


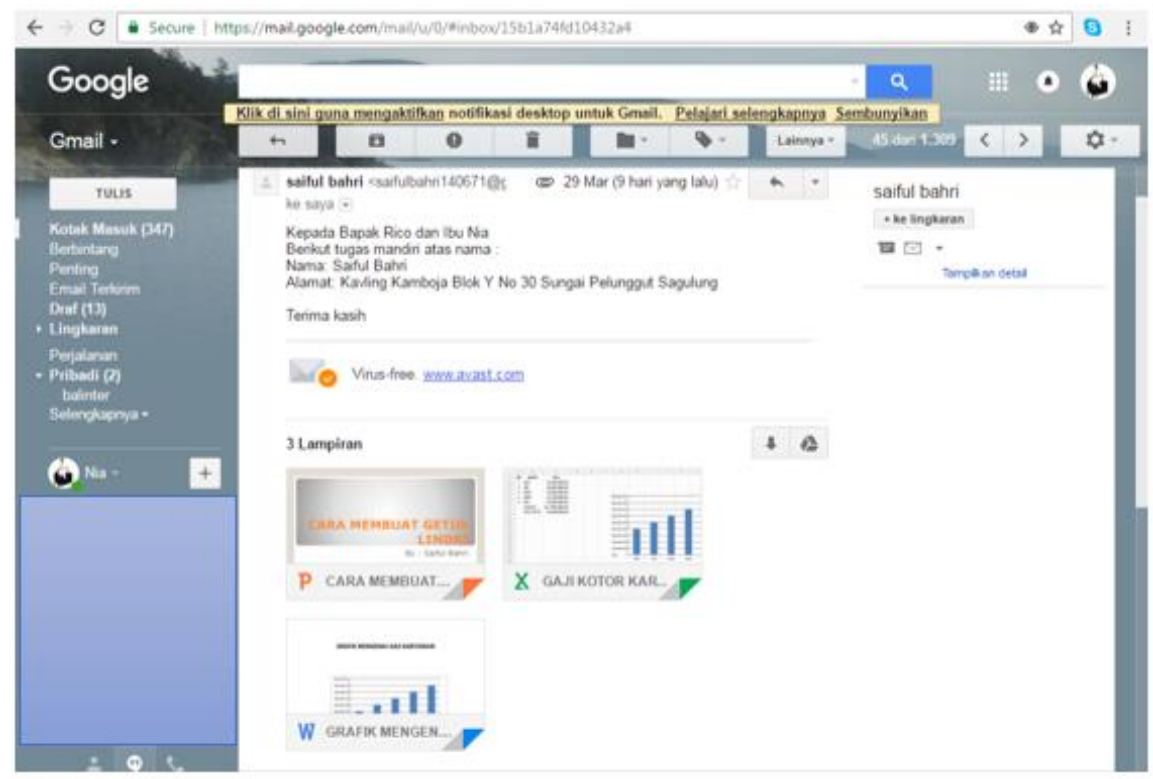

Gambar 7. Hasil Tugas Mandiri dari Peserta Pengabdi dikirim ke alamat e-mail niaekawati1@gmail.com

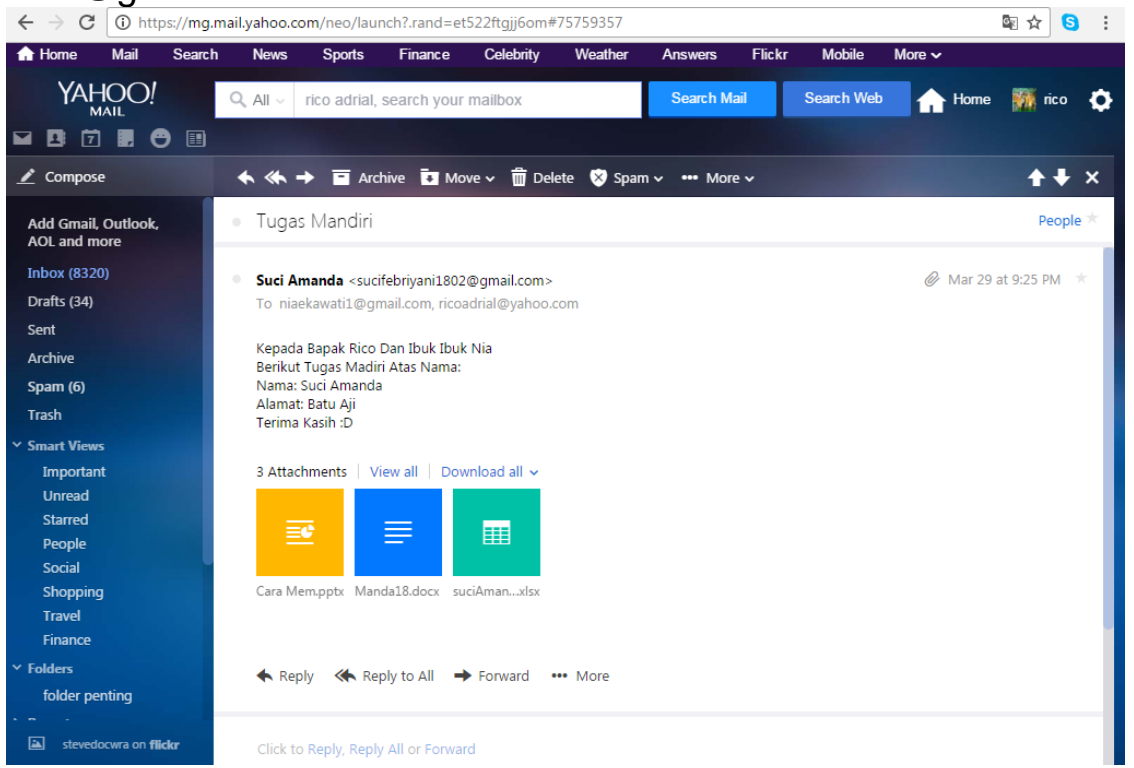

Gambar 8. Hasil Tugas Mandiri dari Peserta Pengabdi dikirim ke alamat e-mail ricoadrial@yahoo.com

Pada saat mengajarkan tugas yang diberikan oleh pengabdi, para peserta masih ada yang bertanya kepada pengabdi, dengan sabar pengabdi memberikan arahan ulang, supaya apa yang diajarkan pada saat pembinaan tersebut dapat dipahami oleh peserta, dan dapat diimplementasikan sehari-hari.

\subsection{Pembahasan}

Pengabdian kepada masyarakat yang dilaksanakan di Kavling Kamboja RT 02 RW 03 Kelurahan Sei Pelungut Kecamatan Sagulung dilakukan sebanyak 3 kali pertemuan. Pada pertemuan pertama pengabdi membahas mengenai Microsoft Excel, pengabdi mengajarkan mulai dari cara membuka aplikasi Microsoft Excel, menerangkan fungsi dari masing-masing Ribbon atau menumenu pada bagian atas di aplikasi Microsoft Excel. Selain itu pengabdi juga 
menjelaskan kegunaan dari sheet dan menjelaskan apa itu cell. Memang cukup sulit menerangkan kepada peserta pengabdian yang ada di Kavling Kamboja RT 02 RW 03 Kelurahan Sei Pelungut Kecamatan Sagulung, karena latar belakang dari semua peserta memang belum pernah menggunakan aplikasi Microsoft Excel tersebut. Awal pembukaan peserta pengabdian sangat antusias, apalagi pada saat pengabdi mengatakan "aplikasi ini dapat digunakan untuk menghitung anggaran belanja ibu-ibu, dan mengatur pengeluaran usaha jika ibu-ibu memiliki suatu usaha". Pengabdi mengatakan lagi adalah "jika Ibu-ibu memiliki usaha dan usahanya cukup lumayan ramai dan mempekerjakan pegawai, pada aplikasi ini kita dapat menghitung gaji-gaji dari setiap karyawan". Mendengar penjelasan pengabdi diatas peserta yang hadir pada saat itu benar-benar ingincepat bias dan antusias harus bisa. Berikut aplikasi Microsoft Execl 2013 yang di ajarkan pada peserta pengabdi.

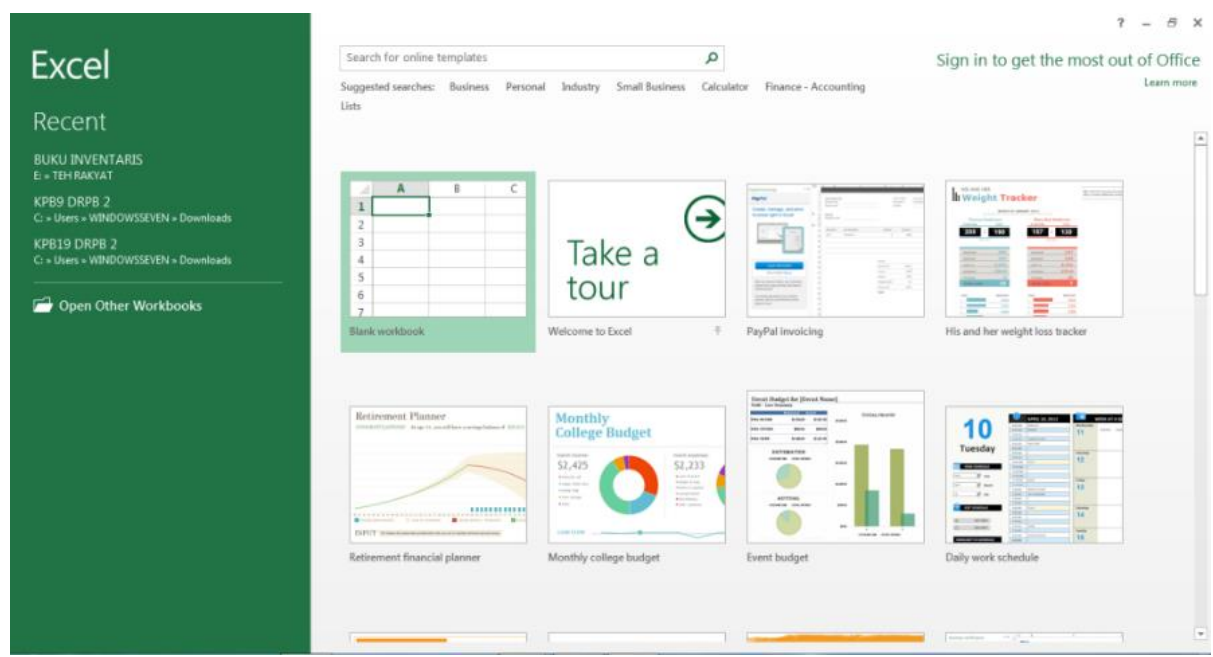

Gambar 9. Tampilan Membuat Book1.xls

Pada pertemuan pertama tersebut, awal pengajaran memberikan contoh mengenai bagaimana menjumlahkan dari beberapa orang yang memiliki gaji, dapat dilihat pada contoh dibawah ini.

\begin{tabular}{|c|c|c|c|}
\hline 4 & A & B & C \\
\hline 1 & No & Nama & Gaji \\
\hline 2 & 1 & Ana & Rp $\quad 400,000.00$ \\
\hline 3 & 2 & Ani & Rp $\quad 500,000.00$ \\
\hline 4 & 3 & Budi & Rp $\quad 600,000.00$ \\
\hline 5 & 4 & Andi & Rp $700,000.00$ \\
\hline 6 & & Anda & Rp $\quad 800,000.00$ \\
\hline 7 & Jum & nlah & $\operatorname{Rp} 3,000,000.00$ \\
\hline
\end{tabular}

Gambar 10. Materi yang disampaikan

Terlihat pada gambar 10, bahwa pengabdi mengajarkan mengenai bagaimana membuat nomor dengan perintah buat nomor 1 dan 2 kebawah selanjutnya simpan kursor dekat posisi angka 2 diantara cell A3 dan B3, terlihat kursor mengecil seperti tambah, lalu drag, buat sampai no 5 saja. Selanjutnya beri nama boleh sesuai yang ada di papan tulis atau buat sendiri tidak apa-apa. Setelah itu isi nilai uang untuk kolom gaji bebas atau ikuti yang ada di depan papan tulis. Maka hasil dapat dilihat pada gambar diatas, untuk membuat kolom 
gaji ada rupiahnya lakukan perintah blok dari cell C2 sampai $C 7$, setelah itu klik kanan $\rightarrow$ format cell $\rightarrow$ pilih accounting $\rightarrow$ pilih symbol Rp Indonesia $\rightarrow$ klik ok. Untuk menjumlah semua gaji beri perintah $=$ Sum(C2:C6) klik enter, maka secara otomatis sudah dijumlahkan dengan rumus tersebut. Peserta pengabdian sangat antusias bahkan ada yang sampai meminta untuk dibuka kursus untuk peserta pengabdian tersebut.

Pertemuan kedua, pengabdi tidak begitu membahas materi karena materi yang disampaikan adalah pembuatan alamat e-mail, dan proses pembuatan cukup menyita waktu yang banyak yang disampaikan oleh rekan pengabdi yang lain. Maka pengabdi hanya membantu peserta pengabdian yang kesulitan dalam memahami dalam pembuatan alamat email tersebut.

Pertemua ketiga, pengabdi menyampaikan materi mengenai Microsoft Power Point, pengabdi mengajarkan mulai dari cara membuka aplikasi Microsoft Power Point, menerangkan fungsi dari masing-masing Ribbon atau menu-menu pada bagian atas di aplikasi Microsoft Power Point. Berikut tampilan awal aplikasi Microsoft Power Point.

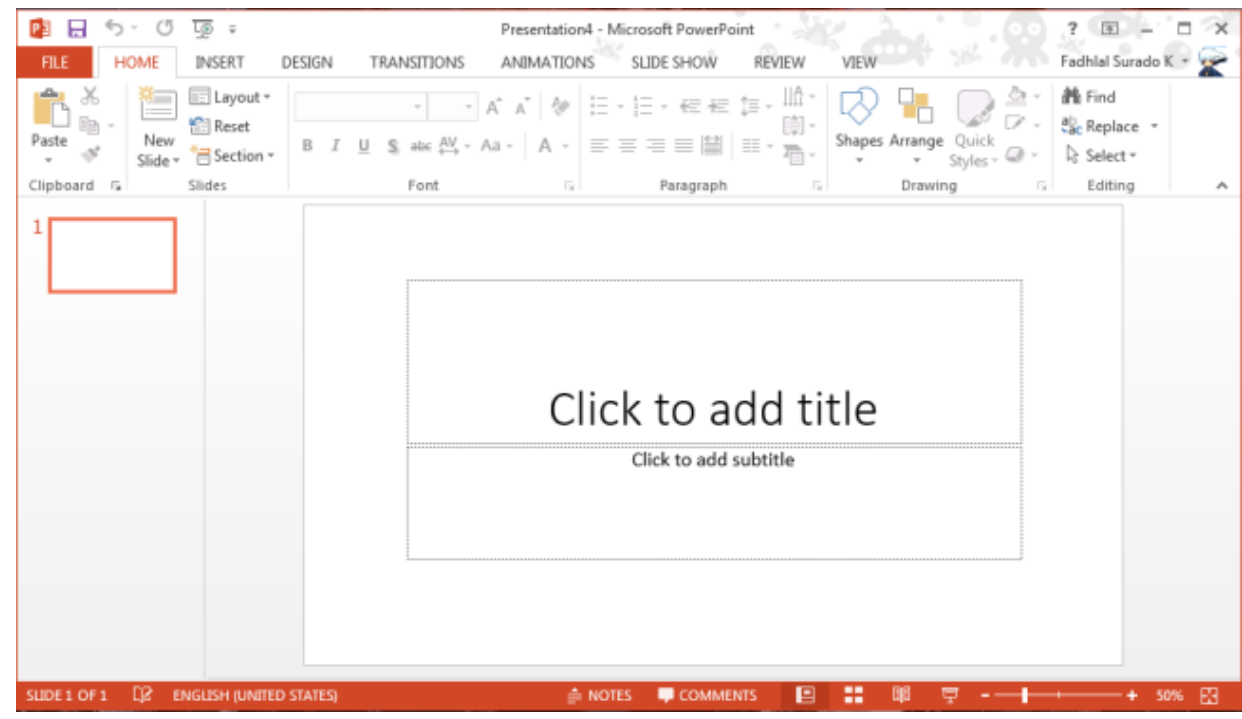

Gambar 11. Tampilan Awal Microsoft Power Point 2013

Pada pertemuan ketiga tersebut, awal pengajaran langsung meminta peserta pengabdian untuk mencoba aplikasi tersebut di depan pengabdi menerangkan langkah apa saja yang harus diketahui, dapat dilihat pada contoh dibawah ini hasil pengerjaan dari salah satu peserta pengabdian. 


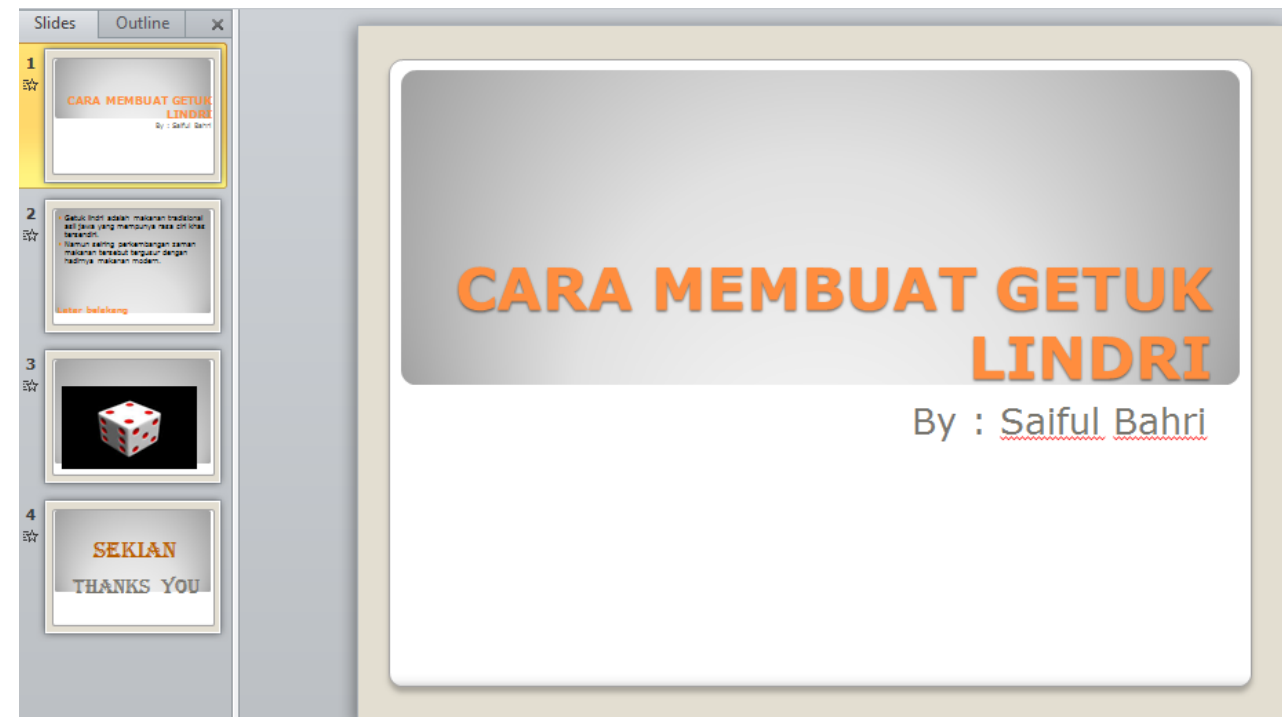

Gambar 12. Hasil pengerjaan salah satu peserta pengabdian

Terlihat pada gambar 12, bahwa pengabdi mengajarkan mengenai bagaimana membuat beberapa slide pada aplikasi Microsoft Power Point 2013, langkah yang harus dilakukan adalah klik tanda ikon $\mathrm{P}$, secara otomatis lembar pembuka power point muncul dan lembar pengerjaan pembuatan slide sebagai pembuka secara bersamaan sudah siap untuk dibuat Judul dari materi/ slide yang akan dibuat. Seperti contoh diatas, peserta yang bernama Saiful Bahri membuat judul untuk mempresentasikan "CARA MEMBUAT GETUK LINDRI". Pengabdi memberikan pengajaran silahkan buat judul masing-masing di bagian "Click to add title" dan nama di bagian "Click to add subtitle". Untuk memulai slide berikutnya maka peserta harus mengklik New slide dan secara otomatis lembar power point bertambah. Pengabdi meminta peserta pengabdian untuk mengetik cerita dari judul yang sudah dibuat sebelumnya. Selanjutnya jika peserta sudah selesai menulis cerita sesuai judul, pengabdi meminta peserta mengklik New slide kembali dan meminta untuk tampilkan ada gambar berdasarkan cerita yang dibuat dengan mengklik (insert picture form file). Pengabdi meminta peserta mengklik New slide kembali dan pilih lembar baru dengan tampilan berbeda atau layout, maka peserta diminta untuk pilih lembar penutup dengan isi ketikannya adalah Sekian dan Terima Kasih. Setelah semua selesai pengabdi meminta peserta untuk menyimpan dan mengirim pada e-mail niaekawati1@gmail.com dan ricoadrial@yahoo.com, bersamaan dengan tugas yang lain, dapat dilihat pada gambar 7 dan 8.

\section{KESIMPULAN}

Pembinaan kerapihan administrasi daerah Kavling Kamboja RT 02 RW 03 Kelurahan Sei Pelungut Kecamatan Sagulung, dapat dikatakan Ibu-ibu PKK dan masyarakat yang ada di daerah Kavling Kamboja RT 02 RW 03 Kelurahan Sei Pelungut Kecamatan Sagulung, sangat antusias dengan kegiatan ini, peserta berharap pengabdi dapat kembali lagi mengajarkan hal-hal yang baru mengenai Microsoft office. Berdasarkan hasil yang dibahas sebelumnya peserta rata-rata dapat mengikuti pembinaan yang dilakukan, sehingga menghasilakan sebuah karya yakni beberapa data/file yang dikirim melalui e-mail. 


\section{SARAN}

Pembinaan kerapihan administrasi daerah Kavling Kamboja RT 02 RW 03 Kelurahan Sei Pelungut Kecamatan Sagulung, sudah dipahami oleh para peserta pengabdi. Sebaiknya ada pengabdi yang lain mengunjungi daerah Kavling Kamboja RT 02 RW 03 Kelurahan Sei Pelungut Kecamatan Sagulung membawakan materi yang berbeda dan ilmu yang bermanfaat bagi warga daerah Kavling Kamboja RT 02 RW 03 Kelurahan Sei Pelungut Kecamatan Sagulung.

\section{UCAPAN TERIMA KASIH}

Penulis mengucapkan terima kasih kepada Lembaga Penelitian dan Pengabdian kepada Masyarakat Universitas Putera Batam yang telah memberi dukungan finansial terhadap pengabdian ini.

\section{DAFTAR PUSTAKA}

Alifiana, M. A. (2018). Peningkatan Pendapatan Rumah Tangga Melalui Pemberdayaan Ibu-Ibu PKK di Kota Kudus. Journal of Dedicators Community UNISNU Jepara, 2(2), 83-90.

LPPM. (2016). Panduan Pengabdian kepada Masyarakat Universitas Putera Batam. Batam: LPPM Universitas Putera Batam.

Rustandi, Andi; Febriani, R. Bunga; Sugiarto, B. R. (2019). PEMBERDAYAAN IBU-IBU PKK MELALUI PELATIHAN ENGLISH FOR BUSINESS DAN ENGLISH FOR TOURISM DI DESA SUKARESIK KECAMATAN SINDANGKASIH KABUPATEN CIAMIS. Abdima Galuh, 1(1), 32-35. Retrieved from https://jurnal.unigal.ac.id/index.php/abdimasgaluh/article/view/2880/2602 